\title{
Mapping glycoconjugate-mediated interactions of marine Bacteroidetes with diatoms
}

\author{
Christin M. Bennke ${ }^{\mathrm{a}, 1}$, Thomas R. Neu ${ }^{\mathrm{b}, 2}$, Bernhard M. Fuchs ${ }^{\mathrm{a}, *}$, Rudolf Amann ${ }^{\mathrm{a}, 3}$ \\ a Max-Planck-Institute for Marine Microbiology, Department Molecular Ecology, Celsiusstr. 1, 28359 Bremen, Germany \\ ${ }^{\mathrm{b}}$ Helmholtz Centre for Environmental Research - UFZ, Department of River Ecology, Brueckstr. 3A, 39114 Magdeburg, Germany
}

\section{A R T I C L E I N F O}

\section{Article history:}

Received 15 January 2013

Received in revised form 29 April 2013

Accepted 6 May 2013

\section{Keywords:}

Bacteroidetes

EPS

CARD-FISH

Lectins

Diatoms

Polysaccharides

\begin{abstract}
A B S T R A C T
The degradation of diatoms is mainly catalyzed by Bacteroidetes and this process is of global relevance for the carbon cycle. In this study, a combination of catalyzed reporter deposition-fluorescence in situ hybridization (CARD-FISH) and fluorescent lectin binding analysis (FLBA) was used to identify and map glycoconjugates involved in the specific interactions of Bacteroidetes and diatoms, as well as detritus, at the coastal marine site Helgoland Roads (German Bight, North Sea). The study probed both the presence of lectin-specific extracellular polymeric substances (EPS) of Bacteroidetes for cell attachment and that of glycoconjugates on diatoms with respect to binding sites for Bacteroidetes. Members of the clades Polaribacter and Ulvibacter were shown to form microcolonies within aggregates for which FLBA indicated the presence of galactose containing slime. Polaribacter spp. was shown to bind specifically to the setae of the abundant diatom Chaetoceros spp., and the setae were stained with fucose-specific lectins. In contrast, Ulvibacter spp. attached to diatoms of the genus Asterionella which bound, among others, the mannosespecific lectin PSA. The newly developed CARD-FISH/FLBA protocol was limited to the glycoconjugates that persisted after the initial CARD-FISH procedure. The differential attachment of bacteroidetal clades to diatoms and their discrete staining by FLBA provided evidence for the essential role that formation and recognition of glycoconjugates play in the interaction of bacteria with phytoplankton.
\end{abstract}

(c) 2013 Elsevier GmbH. All rights reserved.

\section{Introduction}

It has been postulated that more than $90 \%$ of all bacteria species have the potential to live attached [7]. Harsh environmental conditions, for example, high and low availability of carbon and energy sources [55], as well as other environmental stressors, such as high cell densities [45], have been shown to promote aggregate formation in phylogenetically distinct microorganisms. Such aquatic bioaggregates or biofilms are not only populated by bacteria, but diatoms, fungi and protozoa also contribute to their formation by producing extracellular polymeric substances (EPS) $[63,64]$. EPS is mainly composed of polysaccharides, but it also contains proteins, extra cellular DNA and amphiphilic compounds, as well as polymers derived from different habitats, such as humic substances and other polymeric compounds [14,64]. EPS varies from diffuse

\footnotetext{
* Corresponding author. Tel.: +49 4212028 935; fax: +49 4212028790.

E-mail addresses: cbennke@mpi-bremen.de (C.M. Bennke), thomas.neu@ufz.de (T.R. Neu),bfuchs@mpi-bremen.de (B.M. Fuchs), ramann@mpi-bremen.de (R. Amann).

1 Tel.: +494212028545

2 Tel.: +493918109800.

3 Tel.: +494212028930.
}

slimes to a more structured appearance, for example, capsules surrounding distinct cells and microbial adhesive polymers that form "footprints" [36,41]. Whereas capsules are often polysaccharides covalently bound to phospholipids or lipid A molecules on the cell surface, slime is less organized and not covalently bound to the cell surface, but loosely associated and deposited further away from the cell [64]. Another type of EPS is represented by transparent exopolymer particles (TEP) and is mainly generated by diatoms and other phytoplankton cells. TEP production is responsible for diatom sedimentation and is also involved in aggregate formation [41].

EPS has particular properties and functions within microbial communities and, consequently, a novel concept of EPS functionality has been suggested [38]. EPS acts as a diffusive barrier against chemicals, such as xenobiotica and biocides, and protects microorganisms from physical stress like UV-radiation and dehydration, as well as counteracting protozoan grazing $[10,15]$. It also ensures sorption of inorganic ions and organic compounds, promotes exchange of genetic information, as well as cell-to-cell communication and formation of microcolonies [8,15]. In addition, the three-dimensional structure gives mechanical stability and enables the aggregate to resist shear forces [33].

There are several ways to visualize EPS by light microscopy. Fluorescent polysaccharide stains, such as calcofluor white and congo red, bind fairly non-specifically to $1-4$ and $1-3 \beta$-D-glucans. 
Alcian blue, a non-fluorescent copper-containing cation phthalocyanin, binds to anionic molecules such as glucosaminoglycans and can help visualize TEP [37]. Fluorescently labeled lectins are an alternative approach for detecting microbial EPS glycoconjugates [39]. Lectins are carbohydrate-binding proteins of high affinity and specificity which make them suitable tools for detecting specific glycoconjugates [51]. However, they have some disadvantages, such as secondary specificities to non-carbohydrates, or limited penetration to the target polysaccharides $[55,68]$.

In an earlier study, a combination of fluorescence in situ hybridization (FISH) and fluorescent lectin-binding analysis (FLBA) has been used to show that certain glycoconjugates surrounded particular cells and resulted in coherent microcolonies [5]. FISH with rRNA-targeted oligonucleotide probes is a widely used method to identify and quantify environmental microorganisms. However, it has limited sensitivity for small microorganisms with low ribosome numbers [2]. Therefore, the more sensitive method of catalyzed reporter deposition - fluorescence in situ hybridization (CARD-FISH) has been introduced [42].

In the present study, we tested whether the combination of CARD-FISH and FLBA could be used to identify Bacteroidetes cells in the context of the surrounding EPS matrix. Bacteroidetes are a widespread and diverse group of marine bacteria, which are found not only in coastal environments [1] but also in the open ocean $[18,50]$. They occur both free-living in the water column and attached to surfaces such as EPS-rich macroaggregates [11]. Bacteroidetes are known to both produce and degrade EPS [16,40]. In a previous study, performed at the long term ecological research station "Kabeltonne" off the island Helgoland in the German Bight, North Sea, it was shown that Bacteroidetes cell numbers increased rapidly after a diatom-dominated spring bloom with a tight succession of Ulvibacter, Formosa-related group A and Polaribacter clades. Metagenomics and metaproteomics revealed the expression of bacteroidetal glycoside hydrolases $(\mathrm{GH})$ that are specific for polysaccharide degradation [58].

In addition to method development, this CARD-FISH/FLBA study had two goals: (I) to identify in situ Bacteroidetes cells excreting extracellular polymeric substances in the form of capsules or slime as a basis for their attachment, and (II) to examine whether specific clades of Bacteroidetes could be assigned to certain niches in their association with phytoplankton. The study was conducted on $>10 \mu \mathrm{m}$ plankton fractions from Helgoland surface waters, which contained both microbial aggregates and phytoplankton cells.

\section{Materials and methods}

\section{Sampling and sample preparation}

Samples were harvested with the research vessel Ade at station “Kabeltonne”, Helgoland Roads, North Sea (54 $11^{\prime} 30$ N, $\left.7^{\circ} 54^{\prime} 00 \mathrm{E}\right)$ from $1 \mathrm{~m}$ below the sea surface on April 28, 2011 during a diatomdominated spring phytoplankton bloom. Another set of samples was taken at station "Ferry Box" (54 $10^{\prime} 59$ N, $\left.7^{\circ} 5^{\prime}{ }^{\prime} 23 \mathrm{E}\right)$. The seawater samples were fixed with $37 \%$ formaldehyde solution (Fluka; final concentration $1 \%$ ) for $1 \mathrm{~h}$ at room temperature. Volumes of either $500 \mathrm{~mL}$ or $250 \mathrm{~mL}$ were then filtered onto $10 \mu \mathrm{m}$ pore-sized polycarbonate membrane filters with a diameter of $47 \mathrm{~mm}$ (Whatman 7060-4715). Filtration was performed by gravity only, without using a vacuum pump. Filters were dried and stored at $-20^{\circ} \mathrm{C}$ until further analysis.

\section{CARD-FISH and lectin staining}

Catalyzed reporter deposition - fluorescence in situ hybridization (CARD-FISH) was performed according to Thiele et al. [60] but with modifications. Filters were not embedded in agarose prior to CARD-FISH, since preliminary tests with some fluorescently labeled lectins showed non-specific staining with the agarose complex on the filter (see below). All further steps were carried out carefully in order to prevent cell loss. Permeabilization of microbial cell walls and inactivation of endogenous peroxidases were performed as published in Thiele et al. [60]. Hybridization was undertaken in a modified glass humidity chamber preheated at $50{ }^{\circ} \mathrm{C}$ prior to hybridization to equilibrate the thick glass to the temperature. The chamber was lined with a tissue paper soaked with $6 \mathrm{~mL}$ of a formamide-water mix. The formamide concentration of the mix was the same as in the hybridization buffer. The oligonucleotide probes CF319a, POL740, ULV995 and FORM181A (Table 1) were used to detect different Bacteroidetes clades. The probe CF319a targets members of the Bacteroidetes phylum, mainly Flavobacteria, Cytophagia and Sphingobacteria [2,30], whereas POL740 [29] detects the Polaribacter clade, ULV995 targets part of the Ulvibacter clade and FORM181A is specific for the Formosa-related group A [58]. The whole filters were placed face-up into separate Petri dishes and carefully covered with $6 \mathrm{~mL}$ of the hybridization-probe mix [0.9 M NaCl, 20 mM Tris-HCl, pH 8.0, 0.02\% SDS, 1\% blocking reagent (Roche), 35\% formamide, $0.0842 \mathrm{pmol}_{\mu \mathrm{L}^{-1}}$ probe]. The Petri dish was placed carefully in the pre-warmed glass humidity chamber and incubated in the hybridization oven at $46^{\circ} \mathrm{C}$ for $2.5 \mathrm{~h}$. Washing was undertaken in a buffer containing $20 \mathrm{mM}$ Tris- $\mathrm{HCl}$ ( $\mathrm{pH} 8.0$ ), $5 \mathrm{mM}$ EDTA (pH 8.0), $0.07 \mathrm{M} \mathrm{NaCl}$, and $0.01 \% \mathrm{SDS}$ for $15 \mathrm{~min}$ at $48^{\circ} \mathrm{C}$ in a water bath, and for an additional $10 \mathrm{~min}$ in $1 \times \mathrm{PBS}[0.14 \mathrm{M}$ $\left.\mathrm{NaCl}, 2.7 \mathrm{mM} \mathrm{KCl}, 10 \mathrm{mM} \mathrm{Na}_{2} \mathrm{HPO}_{4}, 2 \mathrm{mM} \mathrm{KH} \mathrm{PO}_{4}\right]$ at room temperature. Tyramide signal amplification was performed at $37^{\circ} \mathrm{C}$ for $30 \mathrm{~min}$ in a glass humidity chamber containing $6 \mathrm{~mL}$ of water soaked in tissue paper. The tyramide Alexa594 (Invitrogen) was added to the amplification buffer $[2 \mathrm{M} \mathrm{NaCl}, 10 \%$ dextran sulfate, $0.1 \%$ blocking reagent (Roche), $1 \times \mathrm{PBS}, 0.15 \% \mathrm{H}_{2} \mathrm{O}_{2}, 1 \mu \mathrm{g} \mu \mathrm{L}^{-1}$ tyramide Alexa594]. Filters were washed in $1 \times$ PBS for $15 \mathrm{~min}$ and $2 \mathrm{~min}$ in $96 \%$ ethanol. CARD-FISH filters were subsequently cut into small sections and stained for 20-30 min with different FITC (fluorescein isothiocyanate) and Alexa488-labeled lectins (Table S1) at a concentration of $100 \mathrm{ng} \mu \mathrm{L}^{-1}$. Staining was carried out by placing a $10 \mu \mathrm{L}$ drop of labeled lectin on Parafilm onto which the filter sections were placed face-down and incubated in the dark. After staining, filter sections were washed in excess MQ-water and dried in the dark.

\section{Evaluation of cell loss}

In order to test if CARD-FISH could be performed without agarose embedding, another set of seawater samples from station "Kabeltonne", Helgoland Roads was collected on June 30, 2011. For precise evaluation, $10 \mathrm{~mL}$ and $100 \mathrm{~mL}$ of $3 \mu \mathrm{m}$ pore size pre-filtered fixed seawater were concentrated in duplicates onto $47 \mathrm{~mm}$ diameter polycarbonate membrane filters $(0.2 \mu \mathrm{m}$ pore size, Whatman 7060-4702) with a manual hand pump under low, non-disruptive vacuum $(<500 \mathrm{~Pa})$. The $10 \mathrm{~mL}$ filters were defined as low-cell density filters, and the $100 \mathrm{~mL}$ filters as high-cell density filters. Both low and high density filter replicates were cut and for each experiment four sections per filter were used. In total, eight replicates of low- and high-cell density filters were either embedded in $0.1 \%$ $(\mathrm{w} / \mathrm{v})$ low gelling point agarose (Biozyme, LE-agarose, gel strength of approximately $1000 \mathrm{~g} \mathrm{~cm}^{-2}$ ) or were not embedded. All further steps within the CARD-FISH protocol were performed according to Thiele et al. [60]. The low density filters were hybridized with the oligonucleotide probe CF319a and the high-cell density filters with POL740 (Table 1). Sample evaluation was carried out with the automated epifluorescence microscope Axiolmager.Z2m, including the software package AxioVision 4.7 (Carl Zeiss Microlmaging GmbH) in conjunction with the macros SAMLOC and MPISYS [66]. Cell 
Table 1

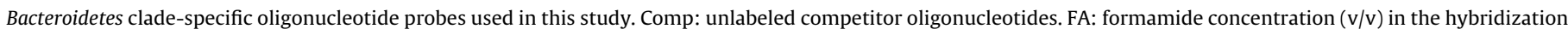
buffer.

\begin{tabular}{|c|c|c|c|c|}
\hline Probe name & Target group & Probe sequence & $\mathrm{FA}(\%)$ & References \\
\hline CF319a & Bacteroidetes phylum & TGGTCCGTGTCTCAGTAC & 35 & [30] \\
\hline POL740 & Polaribacter clade & CCCTCAGCGTCAGTACATACGT & 35 & [29] \\
\hline ULV995 & Ulvibacter clade & TCCACGCCTGTCAGACTACA & 35 & [58] \\
\hline ULV995_Comp1 & Competitor 1 to ULV995 & TCCACTCCTGTCAGACTACA & & \\
\hline ULV995_Comp2 & Competitor 2 to ULV995 & TCCACCССТGTCAGACTACA & & \\
\hline FORM181A & Formosa related group A & GATGCCACTCTAAGAGAC & 25 & [58] \\
\hline FORM181A_Comp & Competitor 1 to FORM181A & GATGCCACTCTTAGAGAC & & \\
\hline
\end{tabular}

enumeration was performed with the ACMEtool software package 0.75 [67].

\section{Confocal laser scanning microscopy}

Samples were examined by a TCS SP5X (Leica, Germany) equipped with an upright microscope and a supercontinuum light source. The system was controlled by the software LAS AF version 2.6.1. Image data sets were recorded using a $63 \times$ NA 1.2 water immersion lens. For excitation, the laser lines at $494 \mathrm{~nm}$ and $594 \mathrm{~nm}$ were selected, whereas emission signals were collected from $510-550 \mathrm{~nm}$ (lectin) to $605-700 \mathrm{~nm}$ (oligonucleotide probe). Filter pieces with bacteria and aggregates were mounted on a slide with Citifluor (Citifluor Ltd., Leicester, UK). Image data sets were projected as maximum intensity projection using the microscope software.

For 3D imaging, the software Imaris version 7.4.1 (Bitplane, Switzerland) was used. For each channel, an isosurface was created and the green channel detecting the lectin was made semitransparent in order to visualize the cells inside the EPS-glycoconjugate matrix.

\section{Results}

In initial control experiments, the lectins did not bind nonspecifically to polycarbonate filters. However, non-specific binding to the agarose used for cell immobilization in the CARD-FISH protocol was observed. Consequently, it was tested if CARD-FISH could be carried out without agarose embedding. Filters containing lowand high-cell densities of planktonic cells were tested with and without embedding in agarose prior to permeabilization with eight replicates of each. It was found that the observed cell loss from all filters was negligible ( $p>0.05$; Table S2) with differences of at most $5 \%$ between replicates. Since this was a qualitative pilot study without exact quantification of cell numbers, embedding in agarose was omitted in order to avoid non-specific binding of lectins.

A screening with 77 commercially available lectins (Table S1) was performed on fixed plankton samples. The samples were taken from Helgoland Roads during the peak of the phytoplankton bloom in spring 2011. Prior to lectin labeling, samples were hybridized with the oligonucleotide probe CF319a targeting the Bacteroidetes phylum. Lectin-specific signals were stronger when FLBA was applied after hybridization compared to labeling carried out before CARD-FISH. This was most likely due to the fact that lectin-based recognition is a non-permanent label ligand that was largely removed during washing procedures in CARD-FISH. From the 77 lectins tested, 12 gave strong signals with various glycoconjugates, for example, the EPS matrix of aggregates and the capsules of either phytoplankton or bacterial cells or slime of microbial microcolonies (Fig. 1A-C). In our samples, it was difficult to distinguish between the LPS layer, capsule or slime because the transitions were gradual and the boundaries were hard to discern. Therefore, the inclusive term "cell surface" recognition has been used in the remainder of the manuscript.

\section{EPS characterization of Bacteroidetes and their subgroups}

Two of the tested lectins, MOA and VRA, bound to glycoconjugates on the surface of CF319a - positive cells, indicating either the presence of cell walls, capsules or slimes (Table 2). Both lectins are specific for galactose in complex glycoconjugates. MOA was retrieved from the mushroom Marasmius oreades and is highly specific for galactose in $\alpha-1$-3-galactose homopolymers or $\alpha-1-3$ galactose- $\beta$-1-4- $N$-acetyl-glucosamine heteropolymers [65]. VRA was isolated from the mung bean Vigna radiate [56]. The VRA lectin also bound to surfaces of bacteria other than Bacteroidetes (Fig. 1B). Both galactose-specific lectins recognized clusters - microcolonies - of Bacteroidetes cells within larger aggregates and showed lectinspecific signals from either the surface of the cells or the matrix in between the cells (Fig. 1C). To characterize Bacteroidetes cells further, the lectins were used in combination with probes targeting the Polaribacter (POL740) and Ulvibacter clades (ULV995), as well as the Formosa-related group A (FORM181A). These clades were highly abundant during and after the spring phytoplankton bloom.

Microcolonies consisting of Polaribacter cells were detected with the galactose-specific lectins MOA (Fig. 2A and Fig. S1A-C) and VRA (Table 2, Fig. S1J-L). In addition, CARD-FISH/FLBA indicated that these microcolonies contained sialic acid residues as detected by the lectin MAA (Fig. S2J-L). This lectin is isolated from the seeds of Maackia amurensis and has a carbohydrate binding specificity for oligosaccharides containing terminal sialic acid- $\alpha$-2,3-galactose residues [26]. Another sialic acid-specific lectin CCA recognized only the cell surface of Polaribacter, indicating either an LPS layer or a capsule (Fig. 2B and S2A-C) and did not visualize microcolony formation of Polaribacter cells as MAA did, indicating different binding abilities for lectins, which was also reported by Böckelmann et al. [5]. CCA was retrieved from the hemolymph of the Californian coastal crab Cancer antennarius and is specific for 9-O-acetylated sialic acids, as well as 4-O-acetylated sialic acids [47]. Similarly, the $N$-acetyl-galactosamine-specific lectin DBA and both mannosespecific lectins PMA (Fig. 2C) and PSA detected only the cell surface of Polaribacter cells (Fig. S3J-L). DBA was isolated from the seeds of Dolichos biflorus and had a carbohydrate binding specificity for terminal non-reducing $\alpha-N$-acetyl-galactosamine [13]. The lectin PMA was isolated from Polygonatum multiflorum and binds to mannose residues [62]. PSA binds to $\alpha$-mannose too, but also to $\alpha$-glucose and $\alpha-N$-acetyl-glucosamine, and was retrieved from Pisum sativa [61].

The surface of Ulvibacter cells (Fig. 2D-F) was labeled with the galactose-specific lectins MOA (Fig. 2D), VGA and VRA, as well as with both sialic acid- and mannose-specific lectins CCA (Fig. 2E), MAA, PMA (Fig. 2F), and PSA similar to Polaribacter (Table 2; for detailed micrographs, see Figs. S1-S3 in the supplementary material). In addition, the surface of Ulvibacter cells was also labeled by the lectins DBA and LOTUS. The latter represents a fucose-specific lectin preferentially binding to $\alpha-1,2$-linked fucose [57]. VGA is another galactose-specific lectin that is obtained from the seeds of Vicia graminea, and it binds mainly to $O$-linked galactose- $\beta$ 1,3-N-acetyl-galactosamine [46]. Besides specifically recognizing 
Table 2

Staining characteristics of the lectins according to their carbohydrate specificity and linkage type. +++ many, ++ few, + rare lectin-positive, - no signals found.

\begin{tabular}{|c|c|c|c|c|c|c|c|c|c|c|}
\hline \multirow[t]{2}{*}{ Carbohydrate specificity } & \multirow[t]{2}{*}{ Lectin } & \multirow[t]{2}{*}{ Linkage type } & \multirow{2}{*}{$\begin{array}{l}\text { Aggregate } \\
\text { matrix }\end{array}$} & \multirow{2}{*}{$\begin{array}{l}\text { Phytoplankton } \\
\text { surface } \\
\text { stain }\end{array}$} & \multicolumn{4}{|c|}{ Bacteroidetes surface stain } & \multirow[t]{2}{*}{ Microcolonies } & \multirow[t]{2}{*}{ Other Bacteria } \\
\hline & & & & & CF319a & POL740 & FORM181A & ULV995 & & \\
\hline \multirow[t]{3}{*}{ Galactose } & MOA & $\begin{array}{l}\text { Gal- } \alpha-1,3-G a l \\
\text { or } \\
\text { Gal- } \alpha-1-3-G a l- \\
\beta-1-4-G l c N A c\end{array}$ & ++ & - & + & + & + & +++ & CF319a/POL740/ULV995 & - \\
\hline & VGA & $\begin{array}{l}\text { Gal- } \beta-1-3- \\
\text { GalNAc }\end{array}$ & ++ & + & - & - & + & ++ & - & \\
\hline & VRA & $\begin{array}{l}\alpha- \\
\text { Galactosidase }\end{array}$ & ++ & - & + & + & - & +++ & CF319a/POL740 & +++ \\
\hline \multirow[t]{2}{*}{ Sialic acid } & CCA & $\begin{array}{l}\text { 9-O-Ac- } \\
\text { NeuAc }>4-\mathrm{O}- \\
\text { Ac-NeuAc }\end{array}$ & ++ & - & + & + & ++ & +++ & CF319a/ULV995/FORM181A & - \\
\hline & MAA & $\begin{array}{l}\text { NANA- } \alpha-2-3- \\
\text { Gal }\end{array}$ & + & - & - & + & + & + & POL740 & - \\
\hline NAcGal & DBA & $\begin{array}{l}\text { GalNAc- } \alpha-1-3- \\
\text { GalNAc }\end{array}$ & + & - & - & + & + & + & - & \\
\hline NAcGal, Fuc-NAcLac & ECOR & $\begin{array}{l}\text { Terminated } \\
\text { Fuc-LacNAc, } \\
\text { GalNAc, Gal, } \\
\text { Lac }\end{array}$ & + & ++ & - & - & - & - & - & - \\
\hline \multirow[t]{2}{*}{ Fucose } & AAL & $\begin{array}{l}\text { Fuc- } \alpha-1,6- \\
\text { GlcNAc or } \\
\text { Fuc- } \alpha-1-3- \\
\text { GalNAc }\end{array}$ & +++ & +++ & - & - & - & - & - & - \\
\hline & LOTUS & $\begin{array}{l}\text { Fuc- } \alpha-1-2-\text { Gal- } \\
\beta-1-4- \\
{[\text { Fuc }(\alpha 1)]-} \\
\text { GlcNAc }\end{array}$ & ++ & ++ & - & - & - & + & ULV995 & - \\
\hline Mannose & PMA & Mannose & + & ++ & - & - & + & + & - & \\
\hline Man, Glc, NAcGlc & PSA & $\begin{array}{l}\text { Branched } \\
\text { Mannoses with } \\
\alpha \text {-Fucose as } \\
\text { determinent }\end{array}$ & ++ & + & - & + & + & + & ULV995 & ++ \\
\hline Not yet determined & IAA & $\begin{array}{l}\text { Not yet } \\
\text { determined }\end{array}$ & +++ & +++ & - & - & - & - & - & - \\
\hline
\end{tabular}




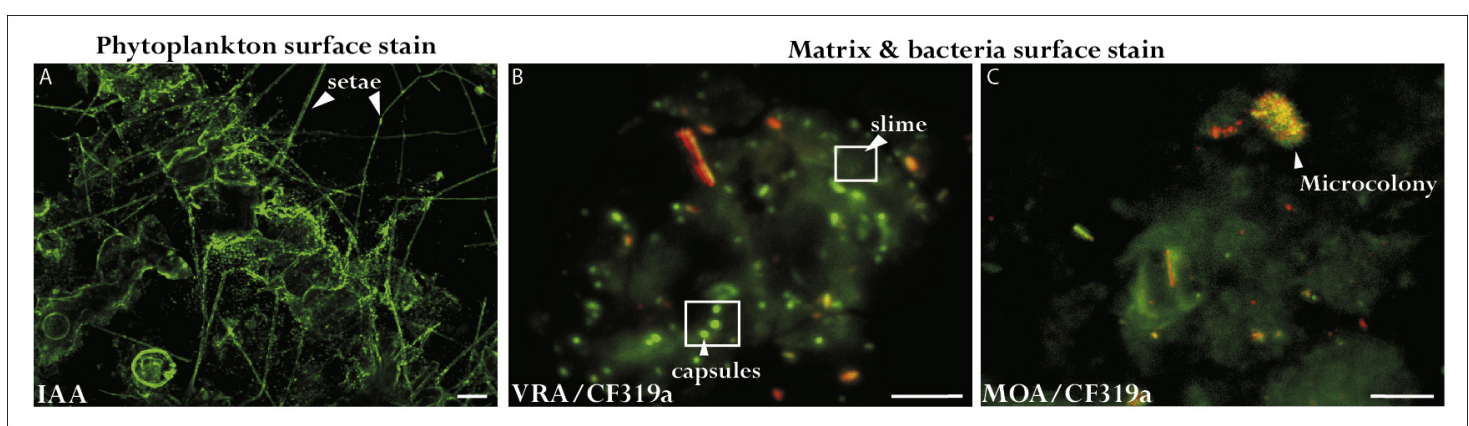

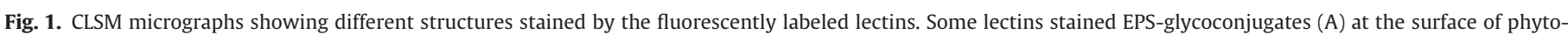

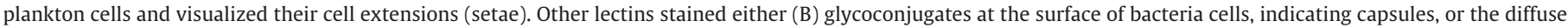

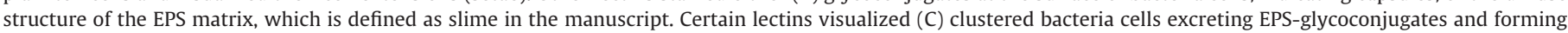

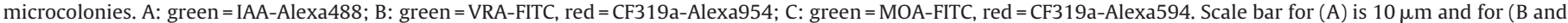
C) is $5 \mu \mathrm{m}$.

the cell surface, MOA, CCA and LOTUS bound to microcolonies of Ulvibacter within the aggregates. In contrast, microcolonies of the Formosa-related group A could only be detected with the lectin CCA (Fig. 2H). The cell surfaces of Formosa-related group A were, with the exception of LOTUS, detected with the same lectins as Ulvibacter (Fig. 2G-I, Figs. S1-S3). In 3D-reconstructed images of the CLSM graphs, Formosa cells appeared surrounded by EPS which indicated capsules (Fig. S4).

\section{Phytoplankton association of Bacteroidetes subgroups}

Three more lectins were able to bind not only to glycoconjugates within the aggregate matrix but also to glycoconjugates produced by phytoplankton cells. The lectins AAL, IAA and ECOR bound distinctly to the surfaces of phytoplankton cells including their setae, but not to the surface of bacteria (Table 2). The lectin AAL is retrieved from the mushroom Aleuria aurantia and

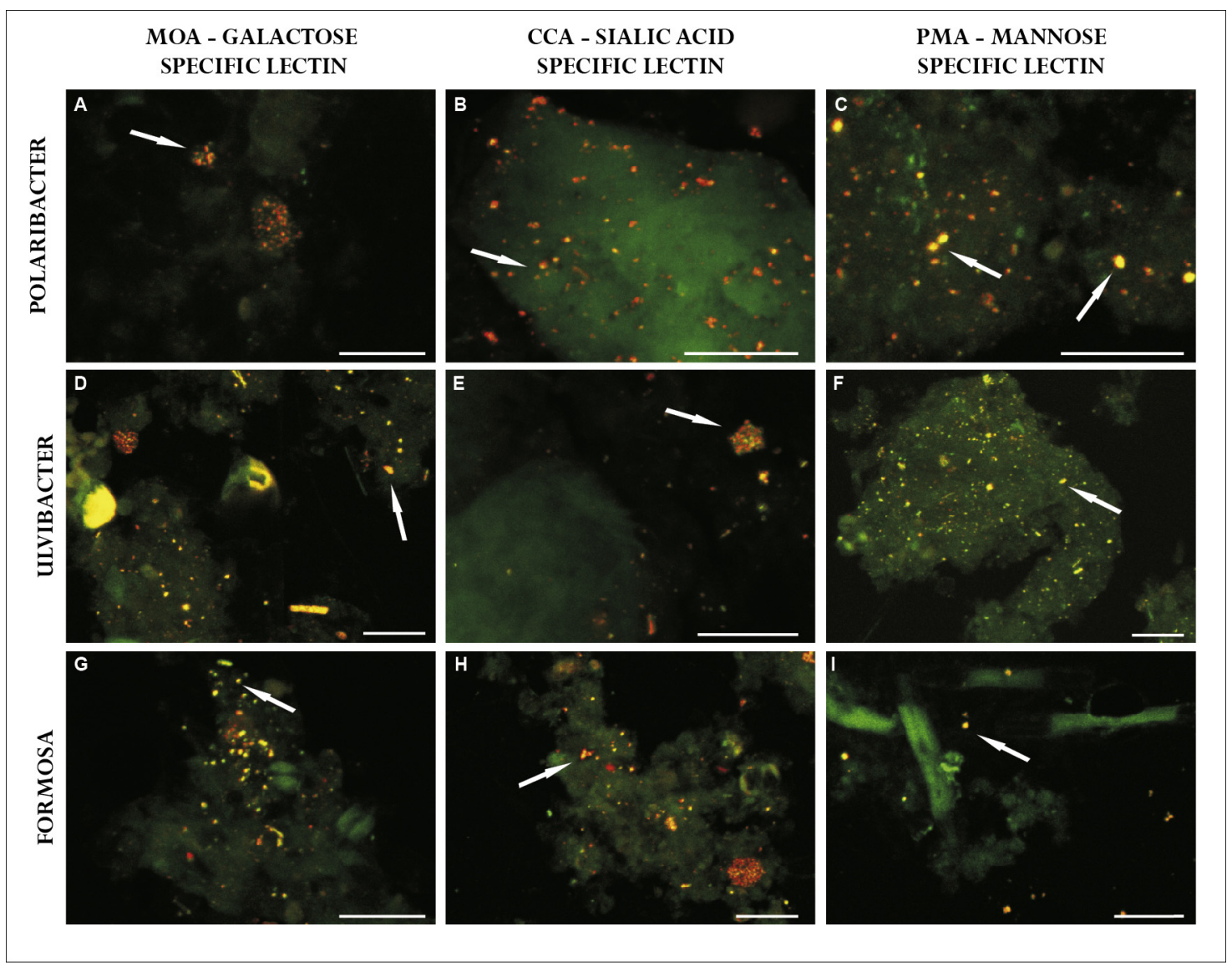

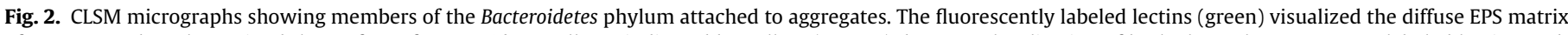

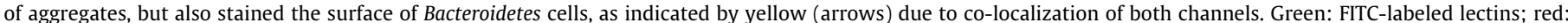

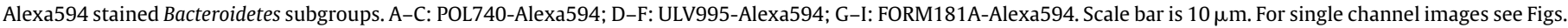
$\mathrm{S} 1-\mathrm{S} 3$ in the supplementary material. 


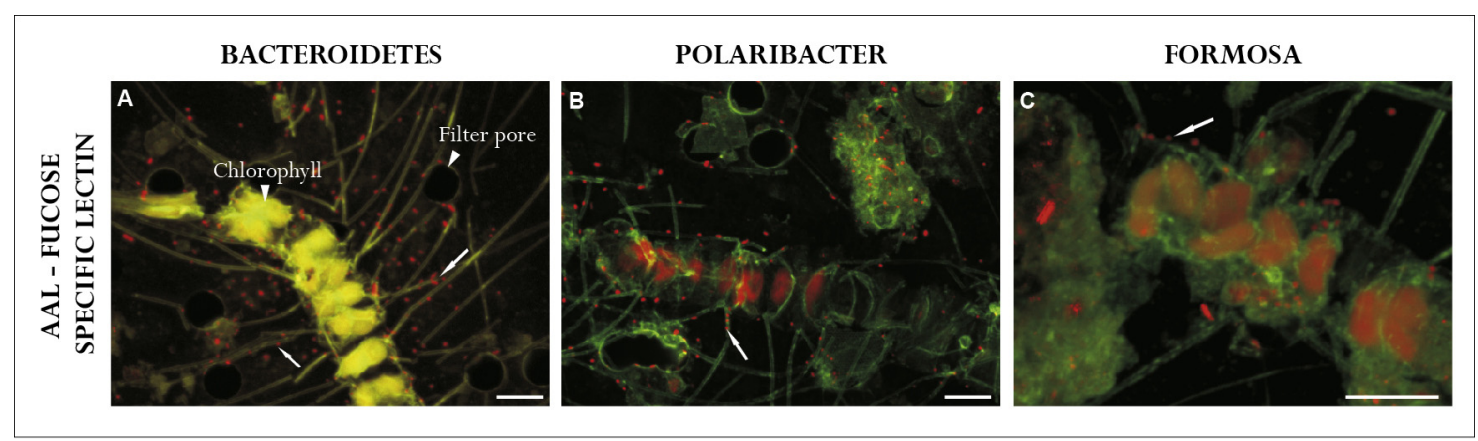

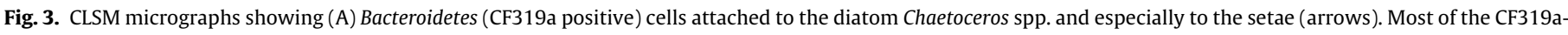

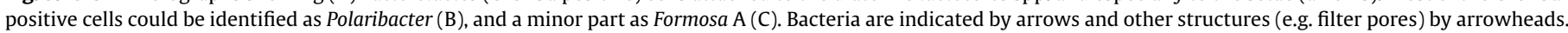
Green: AAL-Alexa488; red: (A) CF319a-Alexa594, (B) POL740-Alexa594, (C) FORM181A-Alexa594. Scale bar is $10 \mu \mathrm{m}$.

favors binding to fucose-linked $\alpha-1,6-N$-acetylglucosamine or to $\alpha$ 1,3-N-acetyl-galactosamine and related structures [17]. The lectin IAA also revealed a strong phytoplankton surface recognition. This lectin is retrieved from the seeds of Iberis amara but since it is not yet purified its carbohydrate binding site has still not been determined [48]. The third lectin ECOR is retrieved from Erythrina corallodendron and recognizes fucosyl- $\mathrm{N}$-acetyl-lactosamine terminated structures and $\mathrm{N}$-acetyl-galactosamine, as well as galactose and lactose [12,59]. Those lectins which bound to the surface of bacteria cells (e.g. MOA, DBA, CCA and MAA) did not bind to the surface of the diatoms or other phytoplankton cells (Table 2).

CLSM micrographs showed that most Bacteroidetes cells, detected with the oligonucleotide probe CF319a, were found attached to aggregates or phytoplankton cell surfaces in spring 2011 (Fig. 3A). The three lectins AAL, IAA, and ECOR labeled the surface of the blooming diatom Chaetoceros, including their setae, where most Polaribacter cells were attached (Fig. 3B). The Formosarelated group A (Fig. 3C) was also found on Chaetoceros cells, but to a lesser extent than Polaribacter. Neither of the flavobacterial clades was associated with any other phytoplankton species in the samples from spring 2011. In contrast, Ulvibacter (Fig. 4) was never found on any Chaetoceros (Fig. 4B) cell, but showed a clear preference for another blooming diatom species, Asterionella (Fig. 4A).

\section{Discussion}

In this study, a protocol was developed that combined cell identification by CARD-FISH with glycoconjugate recognition by FLBA in order to study Bacteroidetes-diatom associations. With this method, the glycoconjugates were revealed by lectin recognition, and they were structurally bound and remained on the filter after fixation, filtration and CARD-FISH. The glycoconjugates that were soluble and not structurally bound did not necessarily remain on the filter, and they most likely went through the pores while filtering. Zippel and $\mathrm{Neu}[68]$ reported insufficient penetration of the lectins toward the target polysaccharide within dense tufa-associated biofilms. For the analyzed samples from Helgoland, this was not observed and 30 min lectin incubation was sufficient for labeling the interior of aggregates. As reported before, the FLBA signals had different appearances, for example, detection of capsules, microcolonies [27] or the overall biofilm matrix [54].

Similar to the previous lectin screenings $[53,68]$, only a limited number out of the whole set of tested lectins (12 out of 77) revealed glycoconjugate signals with our samples. This is not surprising, considering the fact that only five of the 77 lectins tested are retrieved from marine environments, whereas the others are mainly isolated from plants. Furthermore, marine EPS is often sulfated [25] or carries other organic substituents, such as alkyl, succinyl- or pyruvyl-groups, which might interfere with lectin recognition [64]. Within the set of 12 useful lectins in this study, only one (CCA) originated from the marine environment. Notably, seven of the 12 lectins (MAA, ECOR, VRA, VGA, PSA, DBA, and LOTUS) were isolated from Fabaceae, plants interacting closely with Rhizobia and possessing a wide range of different glycoconjugate binding specificities. All remaining unbound lectins had similar carbohydrate specificities as the ones that revealed glycoconjugate signals. Either the specific linkage type was not recognized or substituents affected their binding. Another explanation could be that the incubation time or concentration of these lectins was not sufficient, as reported in previous studies [68].

In the future, there might be several options for characterizing glycoconjugates in such systems in more detail. Firstly, novel lectins retrieved from marine organisms interacting with bacteria may give more details about samples obtained from marine habitats, despite the fact that the EPS of marine phytoplankton might often be sulfated and thus hinder recognition. Secondly, glycoconjugates might be identified by using 'comprehensive microarray polymer profiling' (CoMPP), including polysaccharide-directed probes such as monoclonal antibodies or carbohydrate binding modules (CBM). CoMPP was introduced to address cell wall components of land plants, and provided new insights into structure and function [32]. Recently, this method was used to detect pectin epitopes on green algae [44]. CBMs are enzyme-supporting proteins involved in protein-carbohydrate recognition and bind to a range of different carbohydrates targeting monosaccharides, oligosaccharides or polysaccharides [6]. Fluorescently labeled CBMs were successfully used to identify specific epitopes of land plant cell walls [24]. However, these techniques depend on probes specific for polysaccharides present in marine phytoplankton, and detailed investigations of the present phytoplankton biomass would be required in order to produce new probes.

Distinct spatial distributions of glycoconjugates could be shown for specific Bacteroidetes clades using FLBA. The galactose-specific lectin VRA only recognized the surface of Ulvibacter cells and only microcolonies consisting of Polaribacter cells, yet it did not bind to Formosa group A. VGA bound only to Formosa A and Ulvibacter cells, but not to Polaribacter. Both lectins also bound to a lesser extent to phytoplankton surfaces. Polaribacter and Ulvibacter were able to form microcolonies within aggregates, indicating active growth and production of extracellular polysaccharides, which has also been suggested for marine Bacteroidetes by genome annotation [19]. In contrast, Formosa A cells rarely formed microcolonies (detected with the lectin CCA), but they frequently attached as single cells to the aggregates.

All three Bacteroidetes clades examined in this study were shown to be able to attach to phytoplankton. Sapp et al. [49] and GómezPereira et al. [18] have already observed Bacteroidetes cells within the 'phycosphere' of phytoplankton cells. Also Simon et al. [52] 


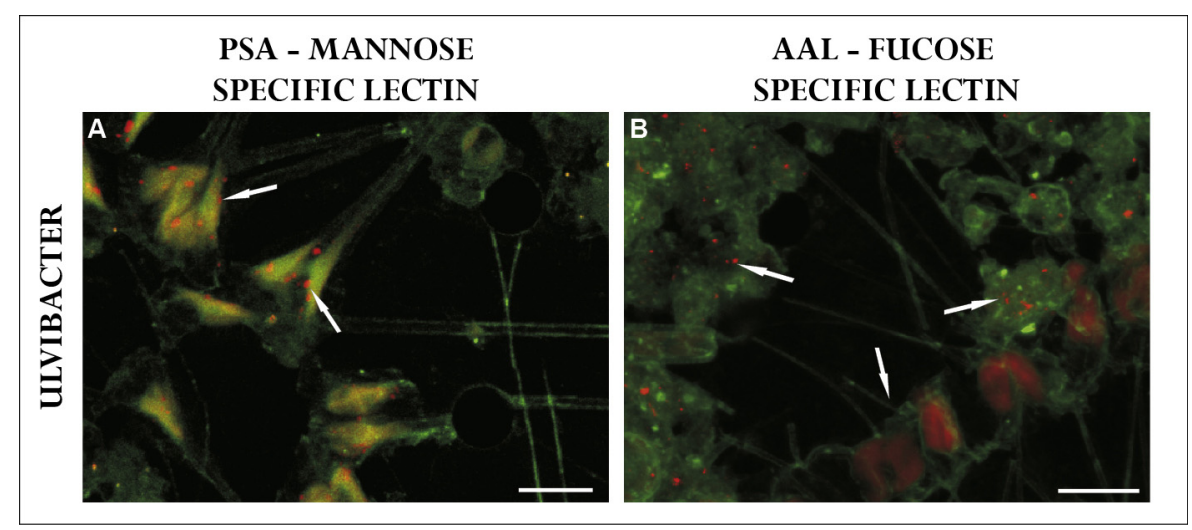

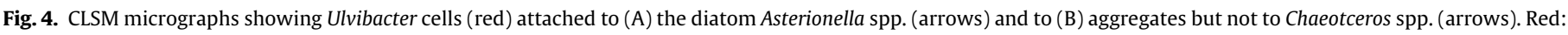
ULV995-Alexa594; green: (A) PSA-FITC, (B) AAL-Alexa488. Scale bar is $10 \mu \mathrm{m}$.

reported on high Bacteroidetes cell numbers in the Antarctic Sea while a Phaeocystis spp. bloom occurred, and the cells were embedded in the glycoconjugates produced by these colonial microalgae. In this study, we provide further detail by showing specific associations of Flavobacteria clades to distinct phytoplankton species that most likely represented distinct glycoconjugate-mediated interactions.

In the past, several studies have reported on the composition of EPS produced by diatoms $[4,23,28,35]$. Its composition was shown to depend on the species, but consists mainly of rhamnose, fucose, galactose and mannose [22,34]. This was reflected in our study by the binding of fucose-specific (e.g. AAL), but also galactose- and mannose-specific, lectins. Bacteroidetes are well known for their utilization of algal polysaccharides [21,49,58]. Genome analyses suggest that marine Bacteroidetes are specialized for particular polysaccharides [3,19]. Here, we could demonstrate by CARD-FISH/FLBA that conspicuous setae of the dominant diatom Chaetoceros were preferred habitats for Polaribacter, whereas cells of the Formosa A group attached mainly to the cell body of this species. Setae are visible as cell wall extensions consisting of fibrous components, silica deposition vesicles and a labiate process apparatus [43], which is involved in mucilage production [31]. Previous studies of Chaetoceros spp. reported high numbers of sulfated extracellular polysaccharides that were directly transferred to the cell surface and deposited as mucilage [22,35]. In other studies, polysaccharide utilization loci consisting of glycoside hydrolases and sulfatases, as well as TonB-dependent outer membrane transporters, were found in Polaribacter genomes and metagenomes $[19,20]$. Recently, Teeling et al. [58], in their study of a Helgoland spring bloom, could assign most of the expressed sulfatases to Polaribacter. Together, these findings support the hypothesis that Polaribacter is able to bind and degrade sulfated fucose-containing polysaccharides coating the Chaetoceros setae. In contrast, members of the Ulvibacter clade were never seen attached to Chaetoceros. They were found on the diatom Asterionella spp., related to polysaccharide composition, but this is unfortunately less studied than Chaetoceros. The labeling of the Asterionella surface with the lectin PSA (Fig. 4A) provided first evidence that this clade of marine Bacteroidetes might be specialized for the binding and degradation of mannose-containing polysaccharides.

\section{Conclusion}

The combination of CARD-FISH and FLBA provided new insights into the molecular basis of the attachment of specific Bacteroidetes clades to planktonic diatoms. This technique has great potential for understanding habitats in situ and possible substrate preferences of attached living bacteria. The three examined clades colonized distinct glycoconjugate microhabitats. Additionally, Polaribacter and Ulvibacter galactose-containing in situ EPS glycoconjugate production could be shown that enabled their permanent attachment to aggregates. Also, the set of lectins used in this study provided the first hint of glycoconjugate distribution and identity in marine bacteroidetal and diatom species. Furthermore, members of the analyzed clades were shown to have preferences for attaching to distinct diatom species, which led to the assumption that they rely most likely on specific diatom-derived EPS glycoconjugates. However, the spatial mapping of the diatom polysaccharides remained incomplete and must await further chemical analyses, as well as the development of additional tools (other lectins, CBMs, and antibodies) for highly specific detection of structural elements [9]. In future, possible experiments with pure bacteria cultures could be conducted in order to gain more knowledge of whether the specific EPS production depends on the availability of particular precursors possibly derived from phytoplankton.

\section{Acknowledgements}

This study was supported by the Max-Planck-Society and the Helmholtz Society. We thank the Captain and crew of the 'Ade' for help with sampling. We are also grateful to Dr. Antje Wichels, Dr. Gunnar Gerdts, Hilke Döpke, Evamaria Krause and Rene Erler from the Biologische Anstalt Helgoland for help with sample procedures and fruitful discussions. We would like to acknowledge the excellent technical assistance of Ute Kuhlicke with the lectin screening and microscopy. We greatly appreciate the substantial contribution of Katy Hoffmann (Technical University of Munich, Germany) for evaluation of the cell loss. The German Federal Ministry of Education and Research (BMBF) supported this study by funding the Microbial Interactions in Marine Systems project (MIMAS, project 03F0480A, http://www.mimas-project.de).

\section{Appendix A. Supplementary data}

Supplementary data associated with this article can be found, in the online version, at http://dx.doi.org/10.1016/j.syapm. 2013.05.002.

\section{References}

[1] Alonso, C., Warnecke, F., Amann, R., Pernthaler, J. (2007) High local and global diversity of Flavobacteria in marine plankton. Environ. Microbiol. 9, 1253-1266. 
[2] Amann, R., Fuchs, B.M. (2008) Single-cell identification in microbial communities by improved fluorescence in situ hybridization techniques. Nat. Rev. Microbiol. 6, 339-348.

[3] Bauer, M., Kube, M., Teeling, H., Richter, M., Lombardot, T., Allers, E., Würdemann, C.A., Quast, C., Kuhl, H., Knaust, F., Woebken, D., Bischof, K., Mussmann, M., Choudhuri, J.V., Meyer, F., Reinhardt, R., Amann, R.I., Glöckner, F.O. (2006) Whole genome analysis of the marine Bacteroidetes 'Gramella forsetii' reveals adaptations to degradation of polymeric organic matter. Environ. Microbiol. 8, 2201-2213.

[4] Berman, T., Holmhansen, O. (1974) Release of photoassimilated carbon as dissolved organic matter by marine phytoplankton. Mar. Biol. 28, 305-310.

[5] Böckelmann, U., Manz, W., Neu, T.R., Szewzyk, U. (2002) Investigation of lotic microbial aggregates by a combined technique of fluorescent in situ hybridization and lectin-binding-analysis. J. Microbiol. Methods 49, 75-87.

[6] Boraston, A.B., Bolam, D.N., Gilbert, H.J., Davies, G.J. (2004) Carbohydratebinding modules: fine-tuning polysaccharide recognition. Biochem. J. 382, 769-781.

[7] Costerton, J.W., Cheng, K.J., Geesey, G.G., Ladd, T.I., Nickel, J.C., Dasgupta, M., Marrie, T.J. (1987) Bacterial biofilms in nature and disease. Annu. Rev. Microbiol. 41, 435-464.

[8] Czaczyk, K., Myszka, K. (2007) Biosynthesis of extracellular polymeric substances (EPS) and its role in microbial biofilm formation. Pol. J. Environ. Stud. 16, 799-806.

[9] de Brouwer, J.F.C., Neu, T.R., Stal, L.J. (2006) On the function of secretion of extracellular polymeric substances by benthic diatoms and their role in intertidal mudflats: a review of recent insights and views. In: Kromkamp, J.C., de Brouwer, J.F.C., Blanchard, G.F., Forster, R.M., Creach, V. (Eds.), Functioning of Microphytobenthos in Estuaries, Royal Academy of Arts and Sciences, Amsterdam, pp. 45-61.

[10] de Carvalho, C.C.C.R. (2007) Biofilms: recent developments on an old battle. Recent Pat. Biotechnol. 1, 49-57.

[11] deLong, E.F., Franks, D.G., Alldredge, A.L. (1993) Phylogenetic diversity of aggregate-attached vs. free-living marine bacterial assemblages. Limnol. Oceanogr. 38, 924-934.

[12] Elgavish, S., Shaanan, B. (1998) Structures of the Erythrina corallodendron lectin and of its complexes with mono- and disaccharides. J. Mol. Biol. 277, 917-932.

[13] Etzler, M.E., Gupta, S., Borrebaeck, C. (1981) Carbohydrate binding properties of the Dolichos biflorus lectin and its subunits. J. Biol. Chem. 256, 23672370.

[14] Flemming, H.C., Neu, T.R., Wozniak, D.J. (2007) The EPS matrix: the "House of Biofilm cells". J. Bacteriol. 189, 7945-7947.

[15] Flemming, H.C., Wingender, J. (2010) The biofilm matrix. Nat. Rev. Microbiol. 8, 623-633.

[16] Fukami, K., Nishijima, T., Ishida, Y. (1997) Stimulative and inhibitory effects of bacteria on the growth of microalgae. Hydrobiologia 358, 185-191.

[17] Fukumori, F., Takeuchi, N., Hagiwara, T., Ohbayashi, H., Endo, T., Kochibe, N., Nagata, Y., Kobata, A. (1990) Primary structure of a fucose-specific lectin obtained from a mushroom Aleuria aurantia. J. Biochem. 107, 190-196.

[18] Gómez-Pereira, P.R., Alonso, C., Oliver, M., van Beusekom, J., Fuchs, B.M. (2010) Distinct flavobacterial communities in contrasting water masses of the North Atlantic Ocean. ISME J. 4, 472-487.

[19] Gómez-Pereira, P.R., Schüler, M., Fuchs, B.M., Bennke, C., Teeling, H., Waldmann, J., Richter, M., Barbe, V., Bataille, E., Glöckner, F.O., Amann, R. (2012) Genomic content of uncultured Bacteroidetes from contrasting oceanic provinces in the North Atlantic Ocean. Environ. Microbiol. 14, 52-66.

[20] González, J.M., Fernández-Gómez, B., Fernández-Guerra, A., Gómez-Consarnau, L., Sánchez, O., Coll-Lladó, M., del Campo, J., Escudero, L., Rodríguez-Martínez, R., Alonso-Sáez, L., Latasa, M., Paulsen, I., Nedashkovskaya, O., Lekunberri, I., Pinhassi, J., Pedrós-Alió, C. (2008) Genome analysis of the proteorhodopsincontaining marine bacterium Polaribacter sp. MED152 (Flavobacteria). Proc. Natl. Acad. Sci. USA 105, 8724-8729.

[21] Grossart, H.-P., Levold, F., Allgaier, M., Simon, M., Brinkhoff, T. (2005) Marine diatom species harbour distinct bacterial communities. Environ. Microbiol. 7, $860-873$.

[22] Haug, A., Myklestad, S. (1976) Polysaccharides of marine diatoms with special reference to Chaetoceros species. Mar. Biol. 34, 217-222.

[23] Hellebust, J.A. (1965) Excretion of some organic compounds by marine phytoplankton. Limnol. Oceanogr. 10, 192-206.

[24] Herve, C., Rogowski, A., Blake, A.W., Marcus, S.E., Gilbert, H.J., Knox, J.P. (2010) Carbohydrate-binding modules promote the enzymatic deconstruction of intact plant cell walls by targeting and proximity effects. Proc. Natl. Acad. Sci. USA 107, 15293-15298.

[25] Hoagland, K.D., Rosowski, J.R., Gretz, M.R., Roemer, S.C. (1993) Diatomextracellular polymeric substances - function, fine structures, chemistry, and physiology. J. Phycol. 29, 537-566.

[26] Imberty, A., Gautier, C., Lescar, J., Perez, S., Wyns, L. (2000) An unusual carbohydrate binding site revealed by the structures of two Maackia amurensis lectins complexed with sialic acid-containing oligosaccharides. J. Biol. Chem. 275, 17541-17548.

[27] Lawrence, J.R., Swerhone, G.D.W., Kuhlicke, U., Neu, T.R. (2007) In situ evidence for microdomains in the polymer matrix of bacterial microcolonies. Can. J. Microbiol. 53, 450-458.

[28] Mague, T.H., Friberg, E., Hughes, D.J., Morris, I. (1980) Extracellular release of carbon by marine phytoplankton: a physiological approach. Limnol. Oceanogr. $25,262-279$.
[29] Malmstrom, R.R., Straza, T.R.A., Cottrell, M.T., Kirchman, D.L. (2007) Diversity abundance, and biomass production of bacterial groups in the western Arctic Ocean. Aquat. Microb. Ecol. 47, 45-55.

[30] Manz, W., Amann, R., Ludwig, W., Vancanneyt, M., Schleifer, K.H. (1996) Application of a suite of 165 rRNA-specific oligonucleotide probes designed to investigate bacteria of the phylum Cytophaga-Flavobacter-Bacteroides in the natural environment. Microbiology 142, 1097-1106.

[31] Medlin, L.K., Crawford, R.M., Andersen, R.A. (1986) Histochemical and ultrastructural evidence for the function of the labiate process in the movement of centric diatoms. Br. Phycol. J. 21, 297-301.

[32] Moller, I., Sorensen, I., Bernal, A.J., Blaukopf, C., Lee, K., Obro, J., Pettolino, F., Roberts, A., Mikkelsen, J.D., Knox, J.P., Bacic, A., Willats, W.G.T. (2007) Highthroughput mapping of cell-wall polymers within and between plants using novel microarrays. Plant J. 50, 1118-1128.

[33] Morikawa, M., Kagihiro, S., Haruki, M., Takano, K., Branda, S., Kolter, R., Kanaya S. (2006) Biofilm formation by a Bacillus subtilis strain that produces gammapolyglutamate. Microbiology (UK) 152, 2801-2807.

[34] Myklestad, S., Haug, A., Larsen, B. (1972) Production of carbohydrates by the marine diatom Chaetoceros affinis var. willei (gran) Hustedt. II preliminary investigation of the extracellular polysaccharide. J. Exp. Mar. Biol. Ecol. 9, 137-144.

[35] Myklestad, S.M. (1995) Release of extracellular products by phytoplankton with special emphasis on polysaccharides. Sci. Total Environ. 165, 155-164.

[36] Neu, T.R. (1992) Microbial "footprints" and the general ability of microorganisms to label interfaces. Can. J. Microbiol. 38, 1005-1008.

[37] Neu, T.R., Lawrence, J.R. (1999) In situ characterisation of extracellular polymeric substances (EPS) in biofilm systems. In: Wingender, J., Neu, T.R., Flemming, H.-C. (Eds.), Microbial Extracellular Polymeric Substances, Springer, Berlin, pp. 21-47.

[38] Neu, T.R., Lawrence, J.R. (2009) Extracellular polymeric substances in microbial biofilms. In: Moran, A.P., Brennan, P., Holst, O., von Itzstein, M. (Eds.), Structures, Relevance and Applications, Elsevier, San Diego, pp. 735758 .

[39] Neu, T.R., Swerhone, G.D.W., Lawrence, J.R. (2001) Assessment of lectin-binding analysis for in situ detection of glycoconjugates in biofilm systems. Microbiology 147, 299-313.

[40] Nichols, C.A.M., Guezennec, J., Bowman, J.P. (2005) Bacterial exopolysaccharides from extreme marine environments with special consideration of the southern ocean, sea ice, and deep-sea hydrothermal vents: a review. Mar. Biotechnol. 7, 253-271.

[41] Passow, U. (2002) Transparent exopolymer particles (TEP) in aquatic environments. Prog. Oceanogr. 55, 287-333.

[42] Pernthaler, A., Pernthaler, J., Amann, R. (2002) Fluorescence in situ hybridization and catalyzed reporter deposition for the identification of marine bacteria. Appl. Environ. Microbiol. 68, 3094-3101.

[43] Pickett-Heaps, J.D. (1998) Cell division and morphogenesis of the centric diatom Chaetoceros decipiens (Bacillariophyceae) II. Electron microscopy and a new paradigm for tip growth. J. Phycol. 34, 995-1004.

[44] Popper, Z.A., Michel, G., Herve, C., Domozych, D.S., Willats, W.G.T., Tuohy, M.G., Kloareg, B., Stengel, D.B. 2011 Evolution and diversity of plant cell walls: from algae to flowering plants. (Eds.), Annual Review of Plant Biology, vol. 62, Annual Reviews, Palo Alto, pp. , 567-588.

[45] Prakash, B., Veeregowda, B.M., Krishnappa, G. (2003) Biofilms: a survival strategy of bacteria. Curr. Sci. 85, 1299-1307.

[46] Prigent, M.J., Montreuil, J., Strecker, G. (1984) Preliminary investigation of the structure of the carbohydrate component of Vicia graminea lectin, a plant glycoprotein. Carbohydr. Res. 131, 83-92.

[47] Ravindranath, M.H., Higa, H.H., Cooper, E.L., Paulson, J.C. (1985) Purification and characterization of an 0 -acetylsialic acid-specific lectin from a marine crab Cancer antennarius. J. Biol. Chem. 260, 8850-8856.

[48] Romanowska, E. (1964) Reactions of M and N blood-group substances natura and degraded with specific reagents of human and plant origin. Vox Sang. 9, 578-588.

[49] Sapp, M., Schwaderer, A.S., Wiltshire, K.H., Hoppe, H.-G., Gerdts, G., Wichels, A (2007) Species-specific bacterial communities in the phycosphere of microalgae? Microb. Ecol. 53, 683-699.

[50] Schattenhofer, M., Fuchs, B.M., Amann, R., Zubkov, M.V., Tarran, G.A., Pernthaler J. (2009) Latitudinal distribution of prokaryotic picoplankton populations in the Atlantic Ocean. Environ. Microbiol. 11, 2078-2093.

[51] Sharon, N., Lis, H. (2003) Introduction. In: Sharon, N., Lis, H. (Eds.), Lectins, second ed., Kluwer Academic Publisher, The Netherlands, pp. 1-5 (Chapter 1).

[52] Simon, M., Glockner, F.O., Amann, R. (1999) Different community structure and temperature optima of heterotrophic picoplankton in various regions of the Southern Ocean. Aquat. Microb. Ecol. 18, 275-284.

[53] Staudt, C., Horn, H., Hempel, D.C., Neu, T.R. (2003) Screening of lectins for staining lectin-specific glycoconjugates in the EPS of biofilms. In: Lens, P., Moran, A.P., Mahony, T., Stoodley, P., O’Flaherty, V. (Eds.), Biofilms in Medicine, Industry and Environmental Biotechnology, IWA Publishing, UK, pp. 308-326.

[54] Staudt, C., Horn, H., Hempel, D.C., Neu, T.R. (2004) Volumetric measurements of bacterial cells and extracellular polymeric substance glycoconjugates in biofilms. Biotechnol. Bioeng. 88, 585-592.

[55] Stewart, P.S., Franklin, M.J. (2008) Physiological heterogeneity in biofilms. Nat. Rev. Microbiol. 6, 199-210.

[56] Suseelan, K.N., Bhatia, C.R., Mitra, R. (1997) Characteristics of two major lectins from mungbean (Vigna radiata) seeds. Plant Food Hum. Nutr. 50, 211-222. 
[57] Susz, J.P., Dawson, G. (1979) The affinity of the fucose-binding lectin from Lotus tetragonolobus for glycopeptides and oligosaccharides accumulating in fucosidosis. J. Neurochem. 32, 1009-1013.

[58] Teeling, H., Fuchs, B.M., Becher, D., Klockow, C., Gardebrecht, A., Bennke, C.M., Kassabgy, M., Huang, S.X., Mann, A.J., Waldmann, J., Weber, M., Klindworth, A., Otto, A., Lange, J., Bernhardt, J., Reinsch, C., Hecker, M., Peplies, J., Bockelmann, F.D., Callies, U., Gerdts, G., Wichels, A., Wiltshire, K.H., Glockner, F.O., Schweder, T., Amann, R. (2012) Substrate-controlled succession of marine bacterioplankton populations induced by a phytoplankton bloom. Science 336, 608-611.

[59] Teneberg, S., Berntsson, A., Angstrom, J. (2000) Common architecture of the primary galactose binding sites of Erythrina corallodendron lectin and heatlabile enterotoxin from Escherichia coli in relation to the binding of branched neolactohexaosylceramide. J. Biochem. 128, 481-491.

[60] Thiele, S., Fuchs, B., Amann, R. (2011) Identification of microorganisms using the ribosomal RNA approach and fluorescence in situ hybridization. In: Wilderer, P. (Ed.), Treatise on Water Science, Academic Press, Oxford, pp. 171-189.

[61] Trowbridge, I.S. (1974) Isolation and chemical characterization of a mitogenic lectin from Pisum sativum. J. Biol. Chem. 249, 6004-6012.
[62] van Damme, E.J.M., Barre, A., Rouge, P., VanLeuven, F., Balzarini, J., Peumans, W.J. (1996) Molecular cloning of the lectin and a lectin-related protein from common Solomon's seal (Polygonatum multiflorum). Plant Mol. Biol. 31, 657-672.

[63] Vu, B., Chen, M., Crawford, R.J., Ivanova, E.P. (2009) Bacterial extracellular polysaccharides involved in biofilm formation. Molecules 14, 2535-2554.

[64] Wingender, J., Neu, T.R., Flemming, H.-C. (1999) What are bacterial extracellular substances? In: Wingender, J., Neu, T.R., Flemming, H.-C. (Eds.), Microbial Extracellular Polymeric Substances, Springer, Berlin, pp. 1-19.

[65] Winter, H.C., Mostafapour, K., Goldstein, I.J. (2002) The mushroom Marasmius oreades lectin is a blood group type B agglutinin that recognizes the Galalpha1,3 Gal and Galalpha1,3Galbeta1,4GlcNAc porcine xenotransplantation epitopes with high affinity J. Biol. Chem. 277, 14996-15001.

[66] Zeder, M., Ellrott, A., Amann, R. (2011) Automated sample area definition for high-throughput microscopy. Cytom. Part A 79A, 306-310.

[67] Zeder, M., Kohler, E., Pernthaler, J. (2010) Automated quality assessment of autonomously acquired microscopic images of fluorescently stained bacteria. Cytom. Part A 77A, 76-85.

[68] Zippel, B., Neu, T.R. (2011) Characterization of glycoconjugates of extracellular polymeric substances in tufa-associated biofilms by using fluorescence lectinbinding analysis. Appl. Environ. Microbiol. 77, 505-516. 